\title{
ANALYSIS OF THE CAPACITY CHANGES IN THE "GARAJEVAC-ISTOK" EXCAVATION BY APPLYING THE GIS TECHNOLOGY
}

\author{
Mirko A. Borisov ${ }^{a}$, Radovan V. Simićb $^{b}$ Vladimir M. Petrovićc, \\ Bogdan B. Bojovićd \\ a University of Novi Sad, Faculty of Technical Sciences, Department of \\ Computing and Control Engineering, Novi Sad, Republic of Serbia, \\ e-mail:mborisov@uns.ac.rs, \\ ORCID iD: Dhttp://orcid.org/0000-0002-7234-6372 \\ ${ }^{b}$ Geodetic Workshop "AŠ", Novi Sad, Republic of Serbia, \\ e-mail: rashasimic@gmail.com, \\ ORCID iD: (iDhttp://orcid.org/0000-0002-3019-0269 \\ ${ }^{c}$ University of Belgrade, Institute of Chemistry, Technology and \\ Metallurgy, Department for Ecology and Technoeconomics, \\ Belgrade, Republic of Serbia, \\ e-mail: vladimirpetrovic.gis@gmail.com, \\ ORCID iD: Dhttp://orcid.org/0000-0003-0745-4008 \\ ${ }^{d}$ Republic Geodetic Authority, Belgrade, Republic of Serbia, \\ e-mail: bogdan.bojovic@rgz.gov.rs, \\ ORCID iD: (Dhttp://orcid.org/0000-0002-1183-2596
}

DOI: 10.5937/vojtehg67-19650; https://doi.org/10.5937/vojtehg67-19650

FIELD: Geosciences

ARTICLE TYPE: Professional paper

ARTICLE LANGUAGE: English

\section{Abstract:}

The paper discusses the concept of construction and monitoring of capacity changes - the volume of the "Garajevac-Istok" excavation (mine), located in the cadastral municipality of Novi Bečej. Namely, in the earlier period, the physical surface of the Earth and geospace in general were shown two-dimensionally (2D), in a plane, by some of the cartographic methods (contour lines, points heights, hypsometry) or three-dimensionally (3D), by modeling of reliefs and relief cards. The cartographic principles of terrain making and visualizing on relief mapping models allow the creation of $3 D$ views, but not enough quality and engineering precise $3 D$ terrain models. In addition, there is a possibility of quantitative and qualitative assessment of the terrain on the mentioned models not to be accurate enough.

ACKNOWLEDGEMENTS: This work was supported by the Ministry of Education, Science and Technological Development, Government of the Republic of Serbia (project No. 176018). 
With new technologies, the 3D geospatial display mode changes, and the concept of digital terrain modeling (DTM) is being applied. The main goal of the work is to create $3 D$ models and to give an analysis of the "Garajevac-Istok" mine for a certain period of exploitation.

Key words: maps, GIS, volume, changes of terrain, DTM, analysis.

\section{Introduction}

The elevation of the terrain (relief) in the cartographic sense can be represented by contours lines, shadows, hypsometry or their combination. Today, GIS technology, i.e. the digital terrain modeling (DTM) method, is increasingly used. Namely, DTM is the mathematical (statistical) representation of the continuous terrain surface based on a representative set of data in the form of points, lines and other characteristic details collected on the ground ( $\mathrm{Li}$ et al, 2005). The surface of the terrain in a digital form can be presented in three ways (Figure 1):

- contour lines;

- the function of the two variables; and

- volumetric (volume) model.

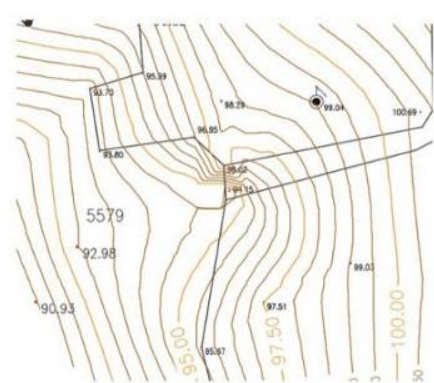

a)

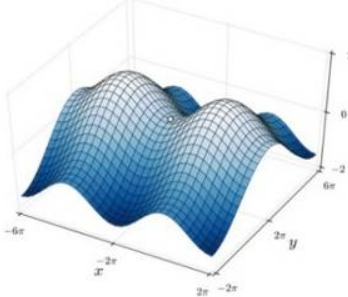

b)

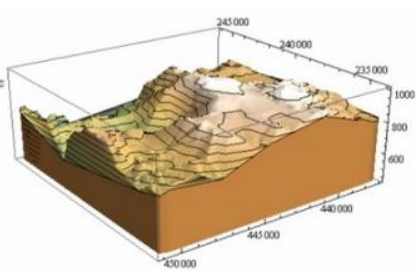

c)

Figure 1 - Terrain preview: a) contours, b) functions of the two variables $Z=f(x, y)$, c) volumetric

Puc. 1 - Отображение местности: а) контуры, b) фрункции двух переменных Z = $f$ $(x, y), c)$ объемное

Слика 1 - Приказ терена: а) изохипсама, b) фрункцијом двеју варијабли Z=f(x,y), c) волуметријски

The subject of this paper is the geomorphological changes in the terrain and the capacity of the "Garajevac - Istok" surface mine in the cadastral municipality of Novi Bečej in the period of 2015, and a comparison with the situation from the period of 2014 and 2013. The analysis of the changes and the comparisons is done by calculating volume and by making terrain profiles. Also, 
the comparison of the condition of the terrain from 2015 is shown by the curve of the capacity (volume) in relation to the physical - topographic surface and the creation of profiles for the purpose of future use of data in the analysis and maintenance of the land using DTM.

Geospatial data is collected and processed automatically to obtain 3D field models in raster or vector formats (Cross \& Moore, 2014). The visualization of field changes can be accomplished by using heights or depths, or can be described using a profile (Ceylan et al, 2011).

Calculation of the excavation and excavation capacity for each part of the capacity curve with regard to the surface is based on the prism calculation method (Omura \& Benton, 2013). The procedure consists of calculating the partial volume of the excavation between the two contour lines. Namely, the partial volume is calculated from the mean surface of the contour (the upper and lower contour of the part "height-depth" being examined), multiplied by the difference in the height of these two contour lines (Chappel, 2014). The surface of the contours can be obtained using GIS or the CAD technology using a digitized map with contour lines (Arrighi \& Soill, 1999). When calculating the cubature in a given region for different epochs in which the change is monitored, it is first necessary to define the position (horizontal) surface $A_{\Delta}$ which occurs by projecting the $3 \mathrm{D}$ surfaces on the horizontal plane along the vertical (Figure 2).

a)

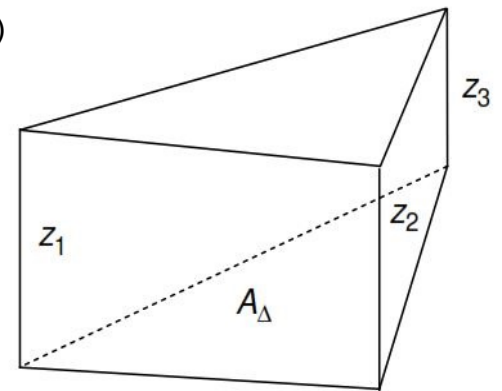

b)

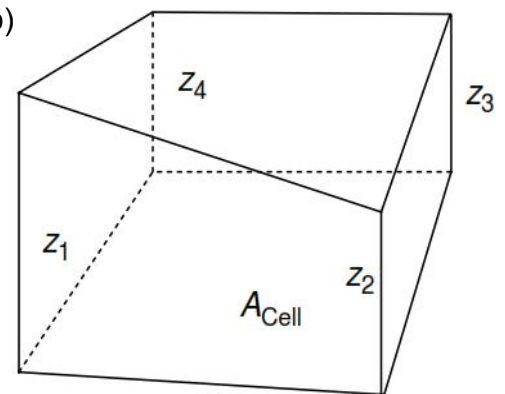

Figure 2 - Calculation of a volume based on a) TIN and b) Grid model Puc. 2 - Расчет объема, основанный на а) TIN и b) Грид модели Слика 2 - Рачунање кубатуре засновано на: а) TIN и b) Грид моделу

The volume $V_{3}$ of the triangulation prism from Figure 2 under a) can be determined by the formula:

$$
V_{3}=\frac{z_{1}+z_{2}+z_{3}}{3} \times A_{\Delta}
$$

where the distances (height) of the DTM points to the horizontal plane. Similarly, for DTM in the form of Grid (Figure 2 under $b$ ), the volume $V_{4}$ can be determined according to the formula: 


$$
V_{4}=\frac{z_{1}+z_{2}+z_{3}+z_{4}}{4} \times A_{\text {cell }}
$$

Based on these two formulas, the volume $V$ of the excavation and the embankment, and based on the DTM engineering design can be expressed:

$$
V=V_{\text {originalDEM }}-V_{\text {newDEM }}
$$

In addition, the resulting values for $V$ can be interpreted as $V>0$ for the excavation, $V<0$ for the embankment, and $V=0$ when there are no changes.

\section{Methodology and technology of work}

The main task in this paper is to calculate the soil (clay) mass of cubes, in order to monitor excavation changes as a result of continuous exploitation for a certain period of time. The implementation process is based on the methods of forming a 3D terrain model for the previous period and the period after exploitation. All modeling and computation of changes and volume masses are carried out in software packages for geo-engineering works (Chappel, 2014).

In addition to the primary task in the work, the control of the display was performed as well as the verification of the calculation of the volume through the transversal profiles, the analysis of the obtained DTMs, and their visualization. The time periods included in the modeling relate to 2013, 2014, and 2015; more precisely, the 3D models are formed on the basis of data related to changes throughout the entire year (January - December).

\section{Research area}

The location covered by the work is located in the Central Banat District, the municipality of Novi Bečej, the cadastral municipality of Novi Bečej, on the eastern border of the construction zone of the city in the area "Garajevac" (Figure 3).

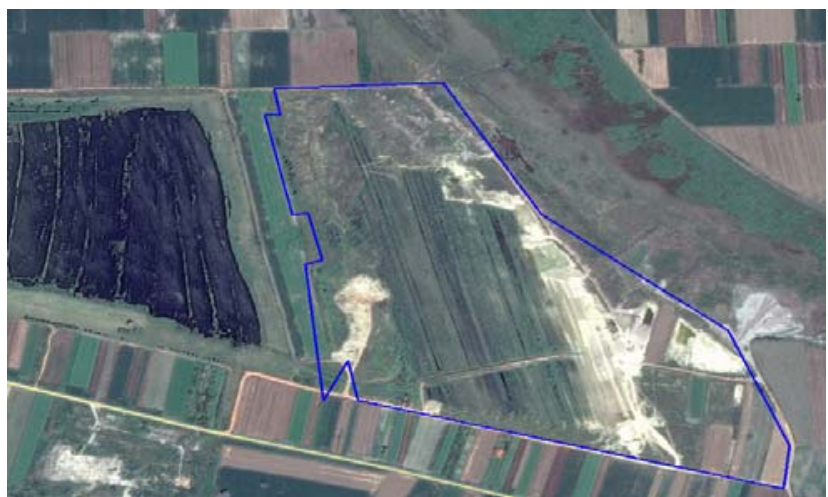

Figure 3 - Display of the the area covered by the work Pис. 3 - Отображение площади, охваченной работами Слика 3 - Приказ подручја које је обухваћено радом 
The plot itself, i.e. the land, belongs to the construction company "Polet" $A D$, Novi Bečej, which realizes the excavation of clay for the needs of the production of construction products (tile, brick, ceramics). At the site, there was already one mine on the west side of the mine covered by this work, which had been exploited in the past, until the moment when all the land owned by the company was used. At that time, the land was purchased for the purpose of opening a new mine, which is being discussed here, in order to provide raw materials for production needs.

\section{Data collection for the DTM formation}

For DTM, relevant data on the surface of the terrain to be modelled are necessary (Šiljeg et al, 2018). For this purpose, relevant data from digital substrates - geodetic plans, which were formed in previous measurements and area analyzes, were used. The existing data in a cartographic form are in CAD formats, where the main carriers of relevant information are points whose positions are described by the $x, y, z$ coordinates, contours and symbols applied to describe topographic relationships of objects (Figure 4).

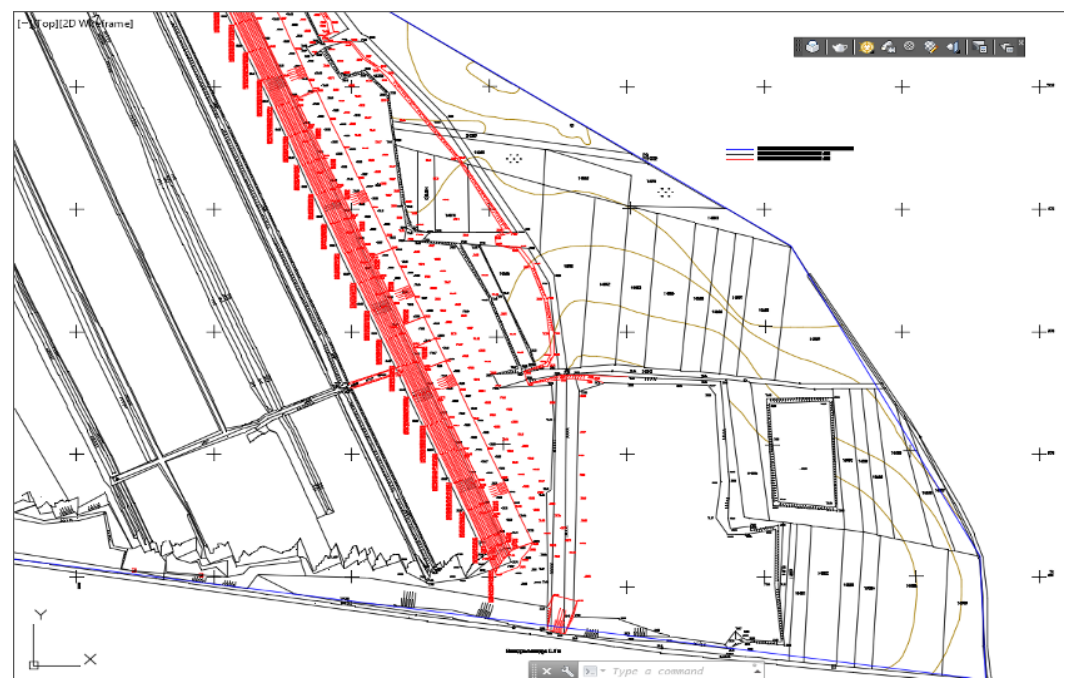

Figure 4 - Existing digital cartographic data

Puc. 4 - Существующие иифровые картографрические данные Слика 4 - Постојећи дигитални картографрски подаци

It is necessary to adapt data for the needs of DTM modeling to enable the required processing (Zhang, 2005). This is generally done by raising the points and isohypses into the $3 \mathrm{D}$ space, since in the original state they are set horizontally with the written heights.

Since the excavation of the material - clay takes place throughout the year, more precisely from the beginning of the spring to the beginning of the winter, it is necessary to collect data for each year from the field in order to monitor the 
changes in the terrain created by the excavation. The field work of data collection is mainly conducted at the end of the year, i.e. after the completion of the excavation for that year. It is practiced that at the end of the year, the current state of the excavation is measured due to favorable meteorological conditions and reduction of field work at the end of the year, when the measurement conditions are worse (Zhang, 2005).

For terrain surface capture, a terrestrial polar method of total cell measurement was used (Simon \& Howel, 2007). The working group consists of four people: two geodetic experts - the more experienced one organizes the measurement process itself and keeps the record/sketch of field measurements (Figure 5), while the other one works with the instrument, and two assistants carrying prisms.

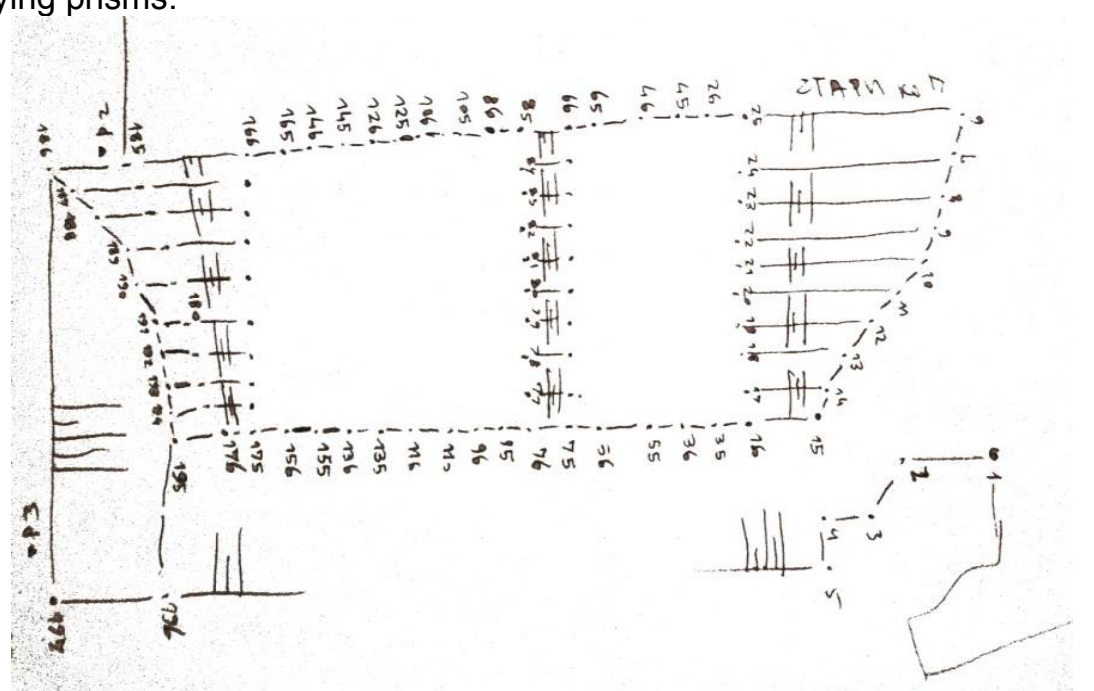

Figure 5 - Field sketch of the measurement

Рис. 5 - Эскиз полевого измерения

Слика 5 - Теренска скица снимања

The geodetic basis for the measurement is established in previous measurements, and relies on the state trigonometric and polygon network. During recording, all measurement data are automatically stored in the total station, so it was not necessary to conduct additional recording minutes other than a sketch of the recording. This also enables simple data transfer in a digital form from the instrument to the computer memory. Recording takes place according to all the rules of the profession (Environmental Systems Research Institute, 2010). The accuracy class is prescribed by the project task, which is compiled by the investor and amounts to:

- standard deviation of the horizontal position $\leq 50 \mathrm{~cm}$; and

- standard deviation of the vertical position $\leq 5 \mathrm{~cm}$. 
Since it is monolithic excavation (Figure 6), the recording is performed on profiles at distances of $25 \mathrm{~m}$, with exceptions in places where significant changes in the terrain occur, and where the recording is swollen by points. This way of generalizing during recording ensures that the required accuracy is achieved in terms of describing the real surface of the field.

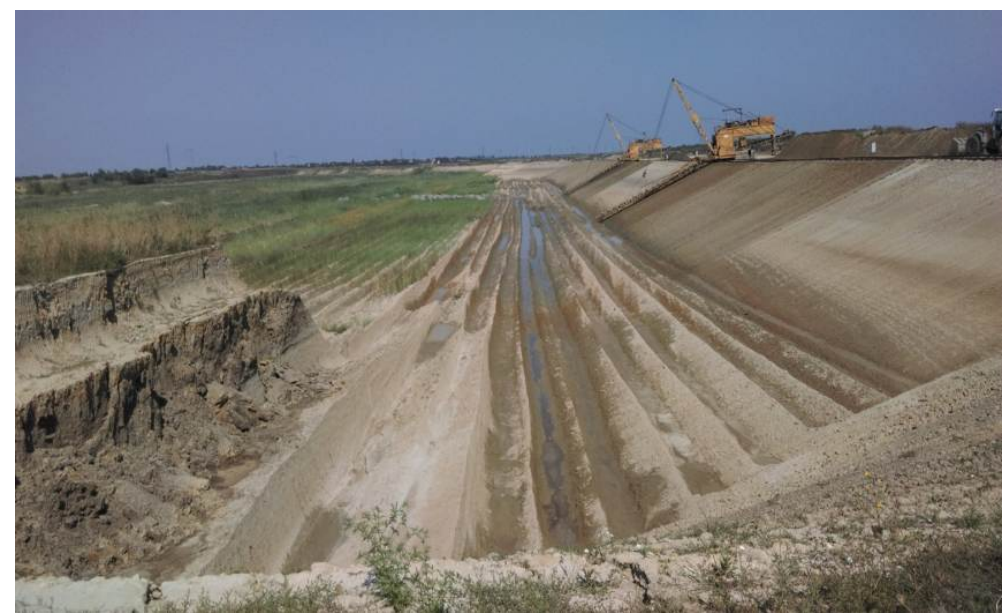

Figure 6 - The excavation site

Puc. 6 - Изображение карьера

Слика 6 - Изглед ископа

In this paper, AutoCAD was used for data preparation, creation of breaklines (structural lines), insight and definition of the model scope as well as for neglecting the existing data that have no impact on modeling. Also, the AutoCAD software package can be used to model 3D complex objects that can be arbitrarily measured, tilted, rotated, and displayed in projections, views and transverse profiles from all directions, etc. (Chappel, 2014).

AutoCAD Civil 3D is a program designed for engineering in construction and geodesy (Autodesk, 2018). It is used for designing, analyzing, producing documentation, visualizing, etc. It relies on an AutoCAD work environment and built-in functions with extensions that allow for additional design options related to the application area (Chappel, 2014). In this paper, AutoCAD Civil 3D was used to create DTM, to calculate the cubature of the soil mass, to control modeling and calculations, as well as for various analyzes and visualizations.

\section{Formation of digital terrain models in the TIN structure}

The first step in forming DTM is to prepare data in AutoCAD. After the recording is completed, the data is stored in the computer memory in a specific format (dwg, dxf, txt, etc.). Data processing starts with loading the new recorded data onto the existing map formed in the previous year (in this case, 2012). This is presented in Figure 7. 


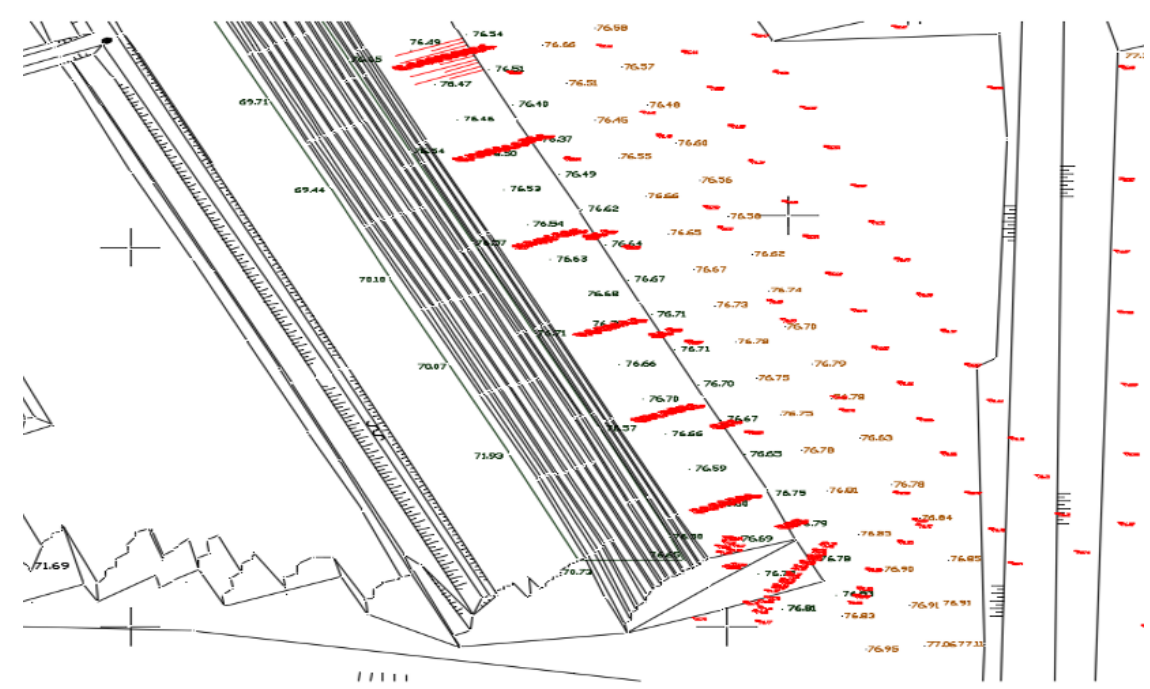

Figure 7 - Downloading the recording data onto the existing map

Puc. 7 - Загрузка замеренных данных на существующую карту

Слика 7 - Учитавање података снимања на постојећу карту

The measurement data from the current year are shown in red and in the following text, for easier explanation, they are called calculative data, while the data from the previous year in black are called zero states.

Points are loaded as 3D, i.e. they are positioned on all three coordinate axes $(x, y$ and $z)$. After that, the structural lines are defined by connecting the points with $3 \mathrm{D}$ polylines (Figure 8 ), which, based on the acquired experience, will play a major role in the quality development of DTM. The connection is done on the basis of the field sketch, in which the characteristic lines are indicated, as an essential element.

Structural lines are very important in the formation of DTM. They introduce a limitation during triangulation which says that the triangle sides connecting the points (the vortices of the triangles, knots) should not cut the structural lines (Šiljeg et al, 2018). The map thus formulated serves as a starting point for further work. In addition, data that will be further used for the DTM formation (points, lines, contours) should be selected.

In this paper, since the field data were collected in the previous years, points are generally used as basic data, complemented by structural lines. It is recommended that prior to moving to the DTM model, those data that are of greater significance should be selected and extracted for easier processing in later stages ( $\mathrm{Li}$ et al, 2005). For this reason, data are also extracted here by such selection, where only data that are in the scope of the new state are taken from the old set of data, while others are ignored because they have no effect on the formation of DTM (Figure 9). 


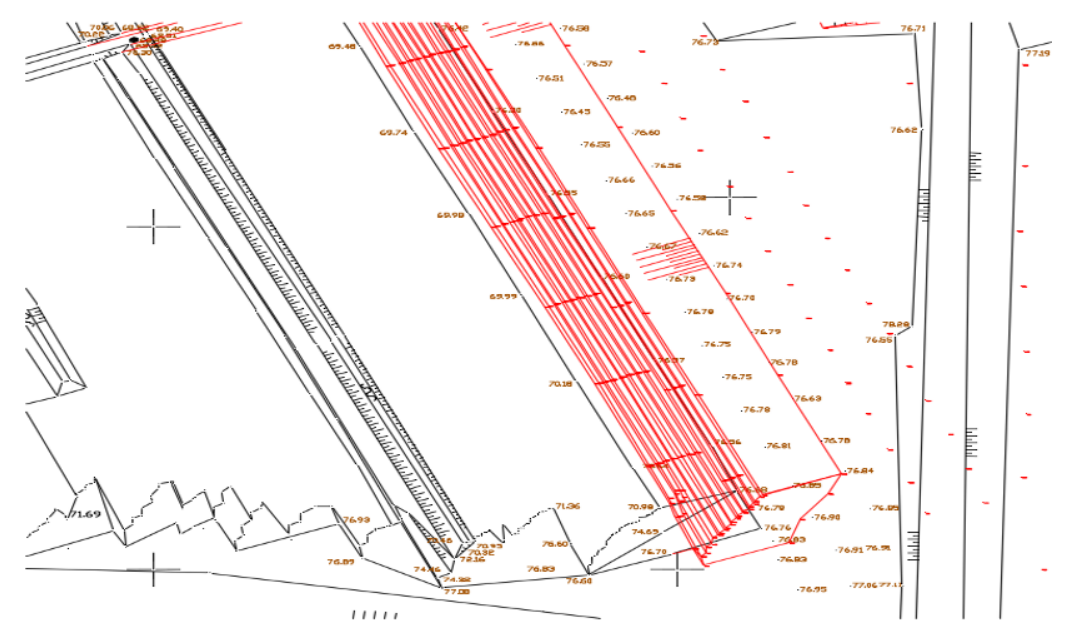

Figure 8 - Construction of the structural (course and ridge) lines Puc. 8 - Проектирование структурных линий Слика 8 - Конструисање структурних линија

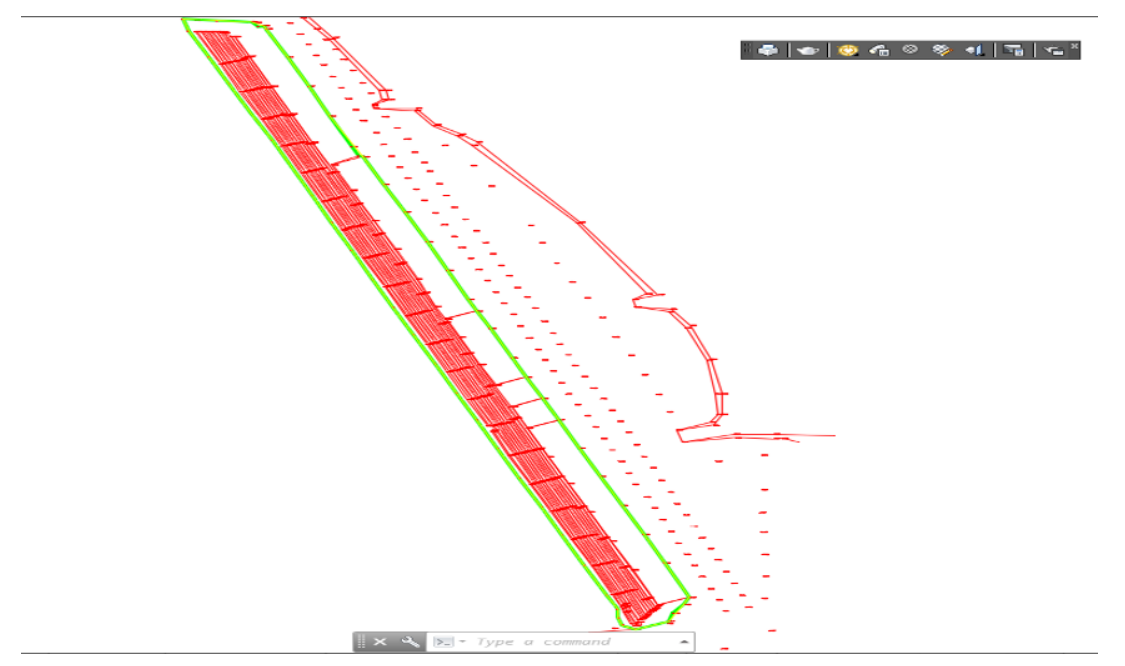

Figure 9 - Separation of the data based on which the DMT is formed Pис. 9 - Выделение данных на основании которых создается ЦММ Слика 9 - Издвајање података на основу којих се формира ДМТ

This sort of data is saved as a new .dwg file, which is processed further on. After that, the DTM is modeled in AutoCAD Civil 3D. The previously prepared data are loaded into the program. The display is identical to that of the classic AutoCAD. In the left part of the program, there is a toolbar (ToolSpace) with 
different models. The Surfaces option is selected, and the right click is applied to create new surfaces (Figure 10).

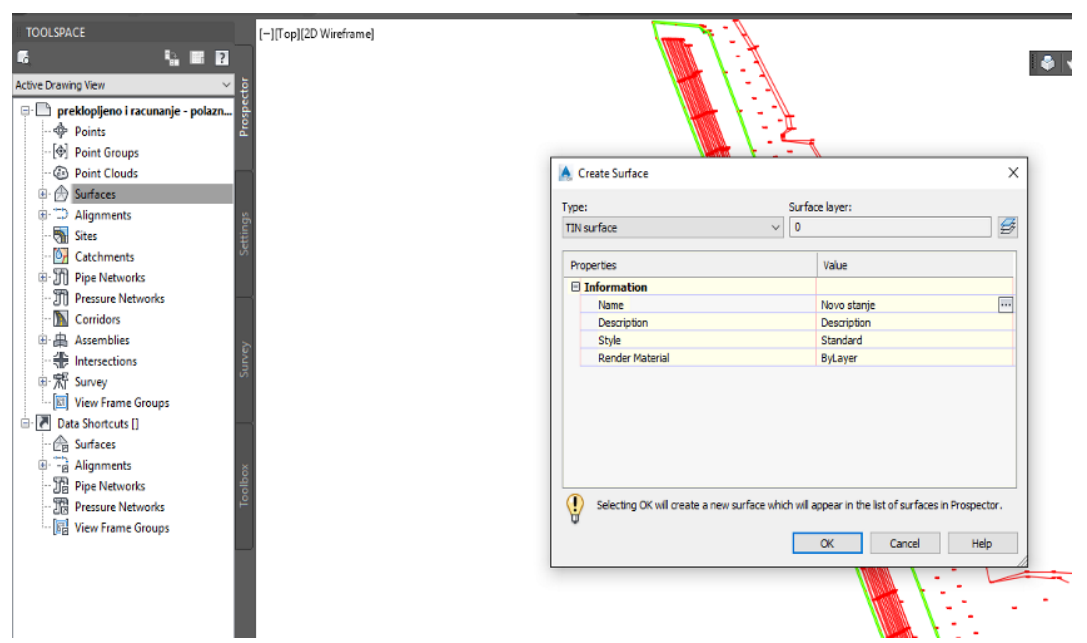

Figure 10 - Creating new surfaces in AutoCAD Civil $3 D$

Puc. 10 - Проектирование новой местности в AutoCAD Civil 3D Слика 10 - Креирање нове површи у AutoCAD Civil 3D

Namely, a window with the basic surface settings appears, where the surface type, in this case the TIN structure, is selected as well as other settings such as the choice of layers, display styles, etc.. After that, the surface itself is defined by adding the data on which the modeling will be done. Given the input data type, and these are 3D points, the option of adding points is chosen (Figure 11).

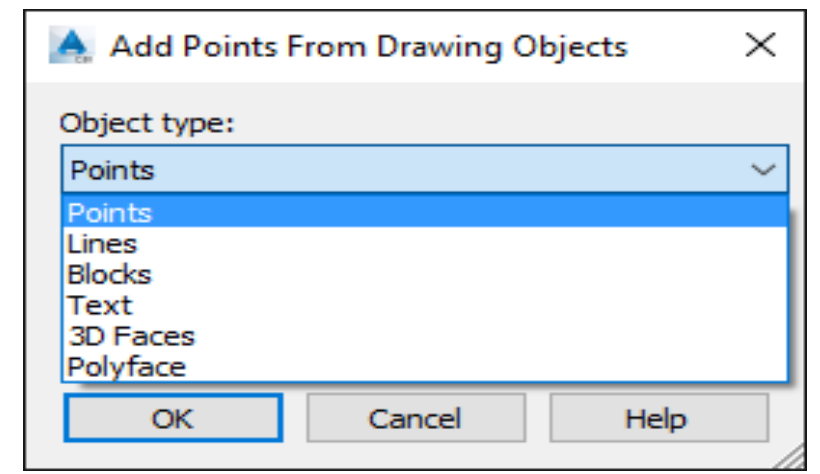

Figure 11 - Input data (3D points)

Puc. 11 - Входные данные (ЗД точки)

Слика 11 - Улазни подаци (ЗД тачке) 
A 3D terrain model was created, i.e. DTM. In the style of the created surface, isohypses with the one-meter equidistance were selected (Figure 12). Visual inspection shows that the contour lines do not represent the given terrain well.

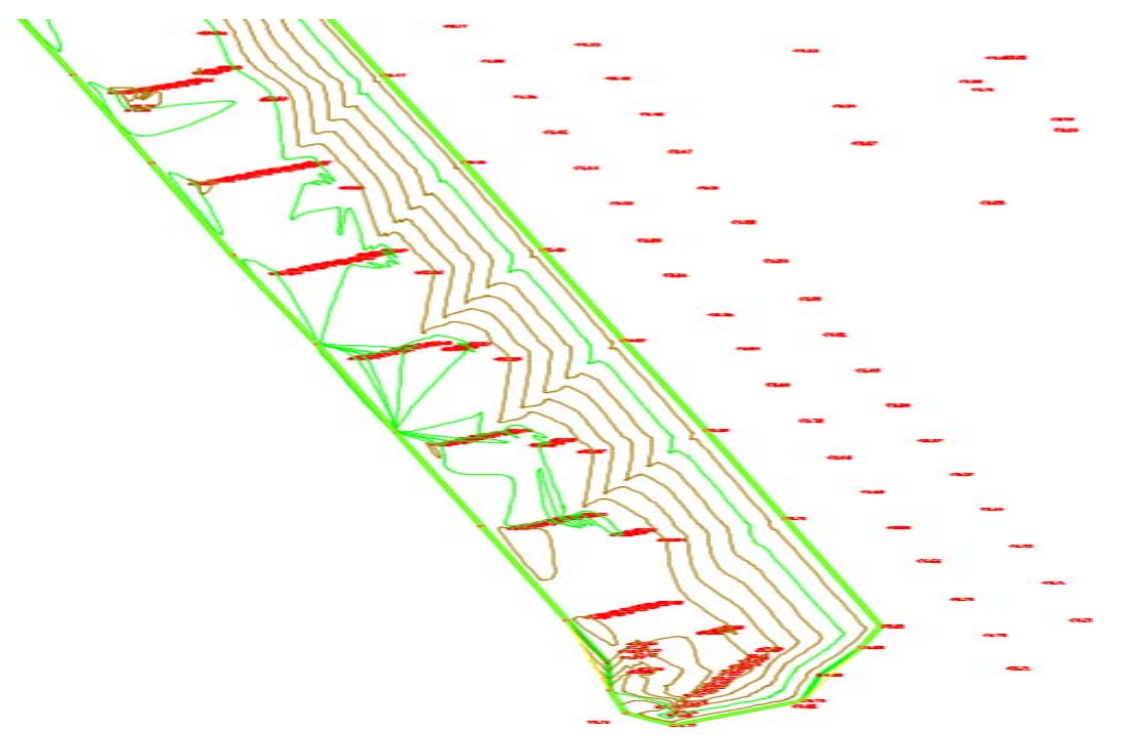

Figure 12 - Appearance of the isohypses of the created DTM

Puс. 12 - Вид изогипсы, разработанной ЦММ

Слика 12 - Изглед изохипси креираног ДМТ

In order to confirm the doubts about the created model, it is necessary to see it in some other views. A 3D view was selected in a realistic form (Figure 13). What is suggested from the display of the isohypses is confirmed by the $3 \mathrm{D}$ view, i.e. the obtained model is not good. The reason for this is the note described earlier, relating to the structural lines. Since the bottom of the excavation has a shape of a saw, it is expected that it will be the same on the model as well. Namely, in these places there are sudden ridges of the terrain and they must be taken into account, i.e. the structural lines already created as 3D polylines.

The input of the structural lines is done in the tool space, where the surface of the new condition is selected by right-clicking on the Breaklines option. After that, there is a selection of 3D polylines which are constructed in the previous steps, in the same way as in the selection of points. Once the selection of a set of structural lines is confirmed, the program automatically processes the 3D model that obtains a new appearance (Figure 14). 


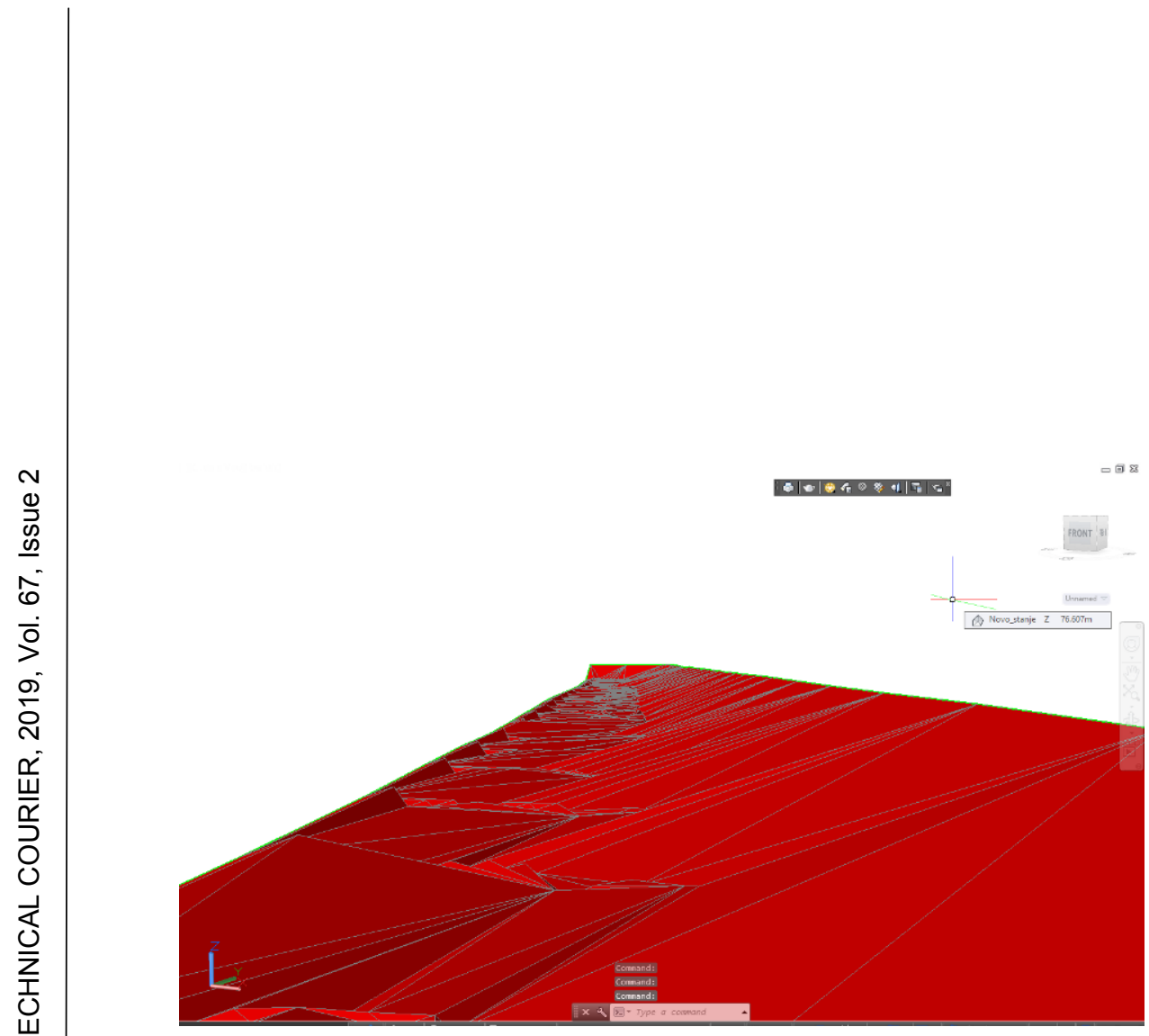

Figure 13-3D model view in a realistic form

Puc. 13 - Изображение ЗД модели в реалистичной фрорме Слика 13 - Приказ ЗД модела у реалистичној форми

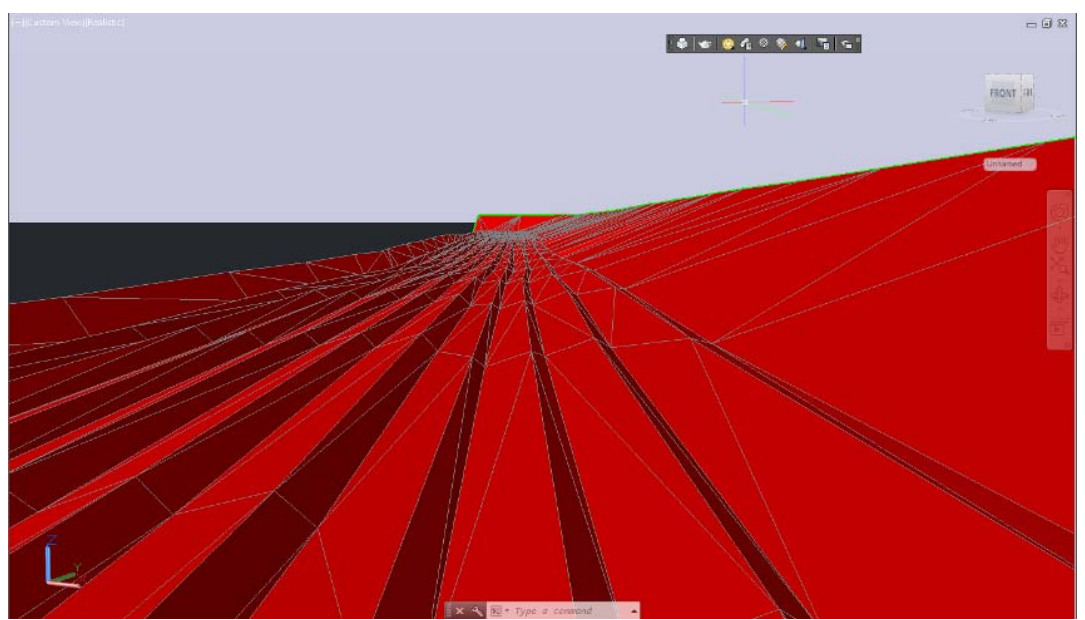

Figure 14 - Appearance of the DTM after adding the structural (course and ridge) lines Puc. 14 - Изображение ЦММ после добавления структурных линий Слика 14 - Изглед ДМТ након додавања структурних линија

By visual inspection of the model and the comparison with the actual surface of the terrain (Figure 15), we can conclude that the formed DTM satisfactorily represents the real physical surface. 


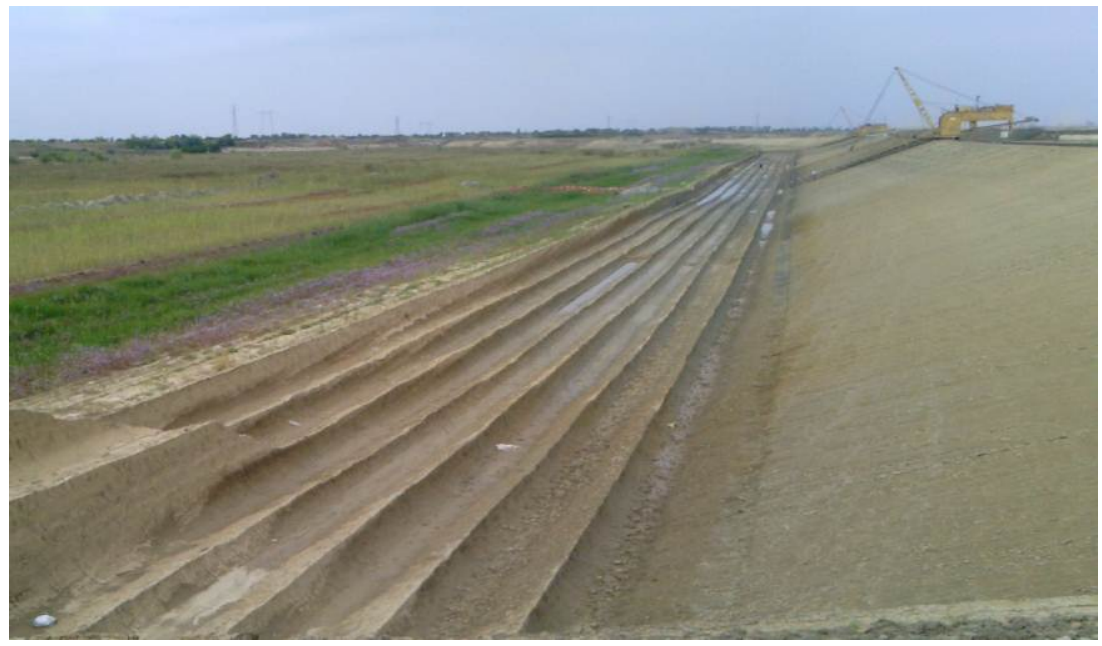

Figure 15 - Appearance of the actual surface of the terrain Puc. 15 - Изображение настоящей поверхности местности Слика 15 - Изглед стварне површи терена

The DTM was created in the TIN structure for 2013, and in this paper it will present the first zero state in the calculation of the volume. After that, it is necessary to create the DTMs for 2014 and 2015, according to the same procedure as explained for the 2013 3D model (Figure 16).

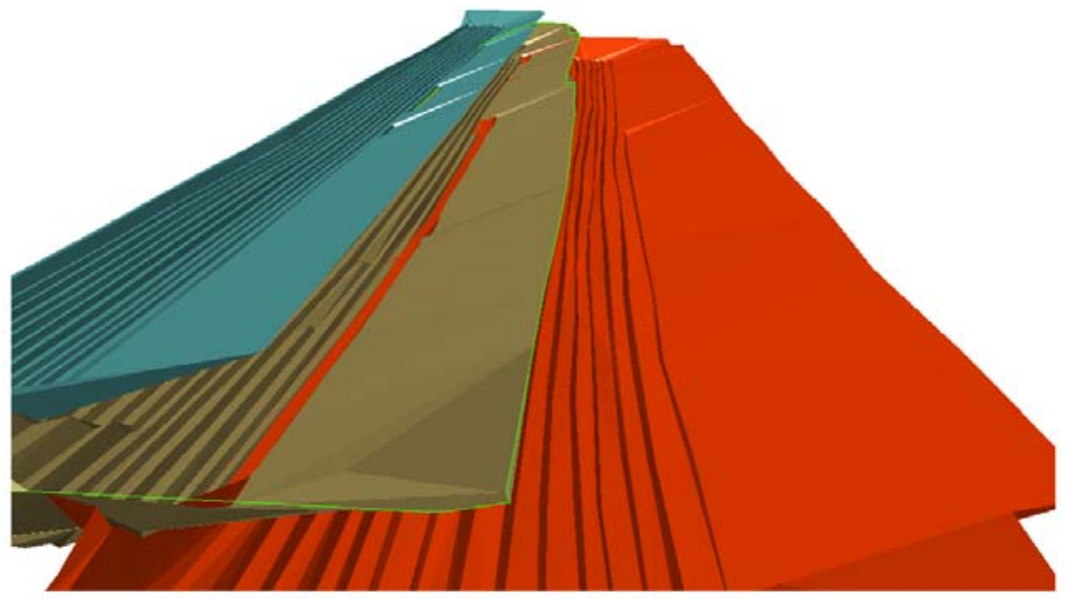

Figure 16 - DTM for years: 2013 (first on the left), 2014 (middle) and 2015 (right) Puс. 16 - ЦММ в 2013 году (первое слева), 2014 году (в середине) и 2015 году (справа)

Слика 16 - ДМТ за године: 2013. (први с леве стране), 2014. (средњи) и 2015. (десни) 
It is clear from the Figure that the models are created only for the excavation for the year they are showing, and do not include data from the following, i.e. neighboring years. More precisely, in the vertical sense, they do not overlap completely. Also, from the top view onto the models, it can be clearly seen that the excavation is shortened in the years after 2013 (Figure 17).

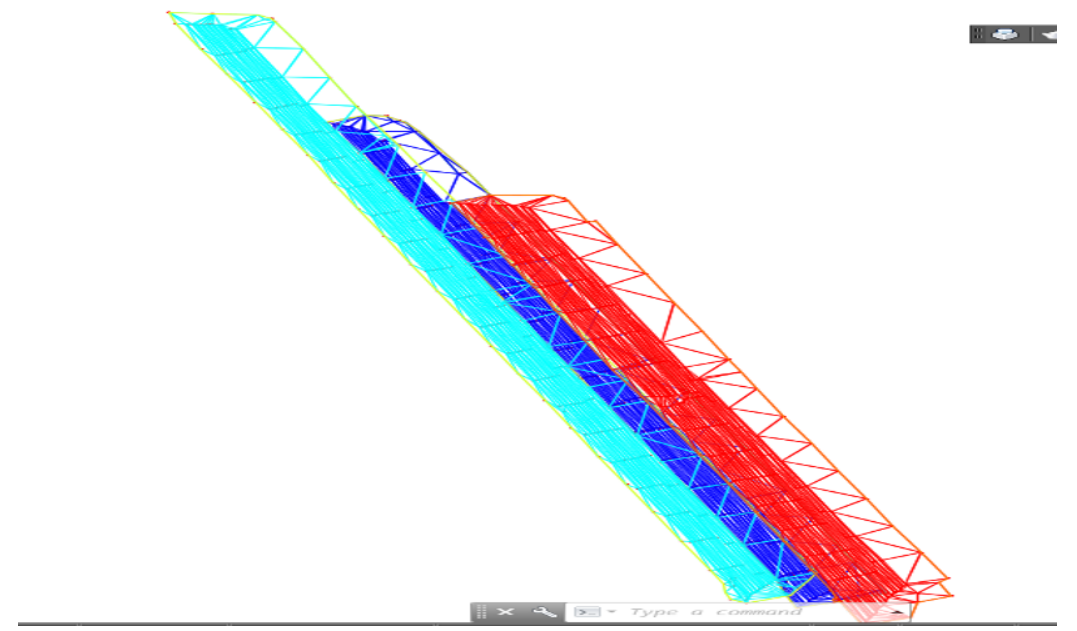

Figure $17-3 D$ model view from above

Pис. 17 - Вид ЗД модели сверху

Слика 17 - Поглед на ЗД модел одозго

In order to be able to calculate the volume of the soil (clay) mass, it is necessary that the boundary of the surfaces for both epochs be identical. This implies the addition of data to the surface in order to complement the border.

The procedure is performed as with the original definition of DTM, by selecting and adding points. The filling was done on the 2013 model with the data from 2014, by selecting the points of the upper rim of the excavation. In this way, we have ensured that the zero model (2013) fully covers the calculation model from 2014 (Figure 18, left). In Figure 18, the right models are only spaced vertically in order to visualize the fitting of the two models.

The supplementary model clearly shows that in some places there is a punching of the calculating surface through the zero surface. The conclusion is that the heights referring to the calculation surface are higher than the heights in that zone on the zero surface. It is to be expected that this phenomenon is numerically interpreted in the calculation of the volume. 


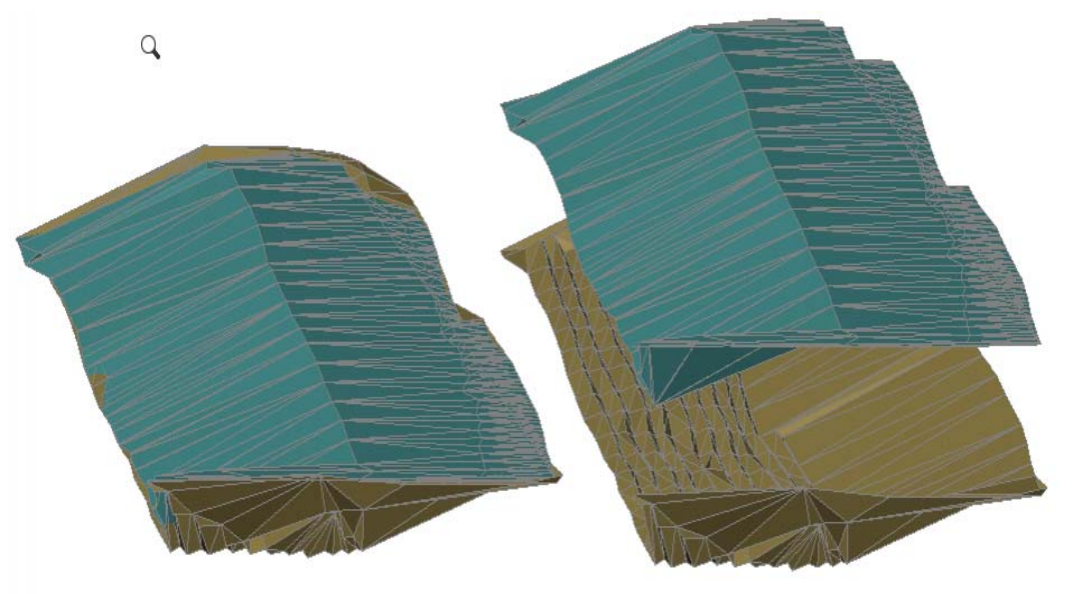

Figure 18 - 2013 model supplemented with the data from 2014

Puc. 18 - Дополненная модель из 2013 года данными из 2014 года Слика 18 - Модел из 2013. године допуњен подацима модела из 2014. године

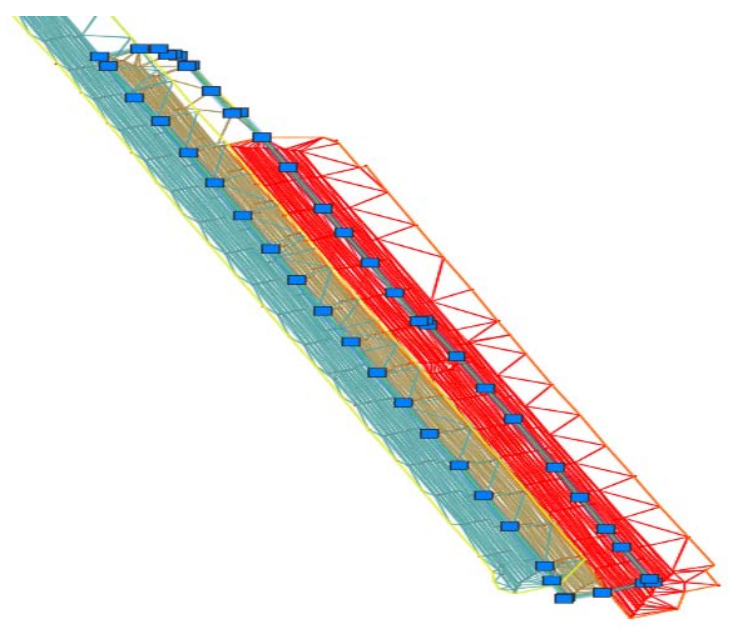

Figure 19 - Calculation boundaries for 2013 and 2014

Puc. 19 - Рубежи расчета 2013 г. и 2014 г.

Слика 19 - Граница рачунања за 2013. и 2014. годину

Also, the 2013 model is longer, so it is necessary to define the boundary of the volume calculation. This is accomplished by drawing 3D polylines connecting the peripheral excavation points from 2014 and adding the boundary in the toolbox, via the Boundaries option (Figure 19). 


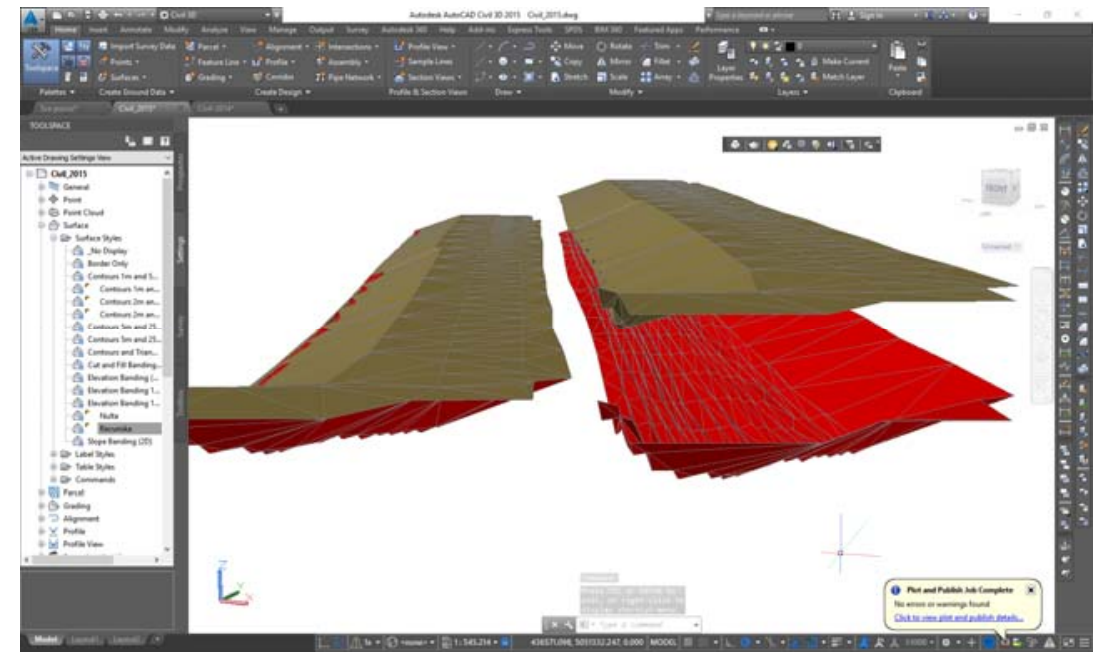

Figure 20 - Models of 2014 and 2015 for calculating the volume Puс. 20 - Модели 2014 г и 2015 г. для расчета объема Слика 20 - Модели из 2014. и 2015. године помоћу којих се обрачунава кубатура 20).

In the same way, the model is expanded for the period 2014- 2015 (Figure

\section{Calculation of the soil (clay) volume}

After the established DTMs for 2013, 2014, and 2015, the calculation of the volume of excavated clay is accessed. All works are of great importance, but especially geodetic works should be carried out carefully and precisely. Namely, when the satisfactory quality of the created DTM is confirmed and accepted, then the volume is calculated in the AutoCAD Civil 3D software package. Calculation is done individually for 2014 in relation to 2013 and for 2015 in relation to 2014. This method of calculation was selected because the company that is the contracting authority monitors the changes of the "Garajvac - istok" surface mine annually.

As already mentioned, the DTMs used for 2013 are used as a zero surface, and those for 2014 as a calculating surface. Calculation of the volume is performed in AutoCAD Civil 3D. In addition, tools are used where the options for calculating the volume of the 3D model of reference surfaces are chosen and the names of the volume models are continuously adjusted, where the base surface is zero, and a comparing one is a calculation surface. A report on the amount of volume can be stored in some of the textual formats. The calculated volumes for 2013.- 2014 have the following values:

- excavation (cut): $42385 \mathrm{~m}^{3}$;

- fill (fill): $147 \mathrm{~m}^{3}$; i.e

- total volume change (net): $42238 \mathrm{~m}^{3}$. 
In the same way, the volume of the excavated clay for the period 2014 2015 is calculated. Based on the established DTM for those years, the following volume values were obtained:

- excavation (cut): $62948 \mathrm{~m}^{3}$;

- fill (fill): $62 \mathrm{~m}^{3}$; i.e

- total volume of changes (net): $62887 \mathrm{~m}^{3}$.

Based on the calculation and based on this period, it can be concluded that the excavated volume values were expected, given that the embankment value is only $62 \mathrm{~m}^{3}$.

\section{Calculation control over transversal profiles}

In the previous chapter, the required volume meters were calculated. The confirmation of the correct calculation was made only on the basis of the conclusion that the created DTMs are correct. In order to perform additional control of the calculation and at the same time to perform the DTM verification, the analysis of the transversal profiles of the DTM should be carried out. In order not to burden the work with unnecessary repetitions of procedures, the average profiles for only one calculated volume will be shown - for $2013-2014$.

The profiles are defined at distances of $25 \mathrm{~m}$, and such a choice is justified by the fact that the survey of the terrain was done by profiles at the same distance. It is estimated that such a profile layout will give good control of the calculation. First, the profiles are arranged for DTM. The direction of the profiles is normal to the direction of the excavation extension, which is largely straightforward. A total of 20 profiles were distributed (Figure 21).
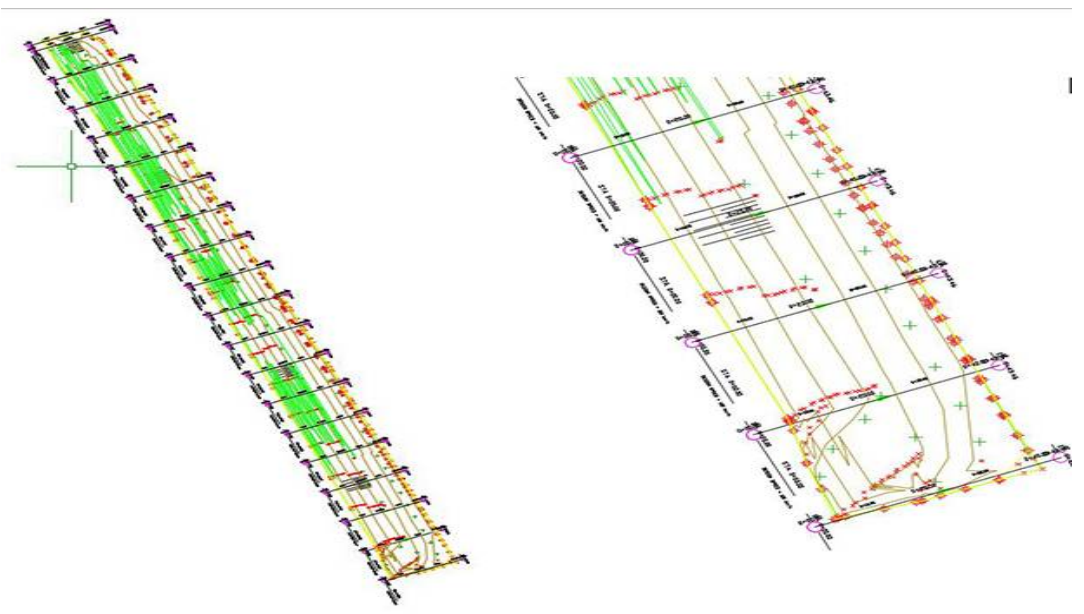

Figure 21 - Splitting the transversal profiles via DTM

Puc. 21 - Распределение поперечных профилей с помощью ЦММ

Слика 21 - Распоређивање попречних профила преко ДМТ 
The arrangement of the profiles is mostly influenced by the configuration of the terrain, and given that in this case it is a monotonous excavation, the chosen profile layout provides quite satisfactory results. When defining a profile, it is necessary to draw out the intersection lines by which the 3D model (cross sections) will be cut and will be made in the direction as stated above. When all the lines are plotted, the program should be set to show that they will actually represent the profile cross section lines (Figure 22).

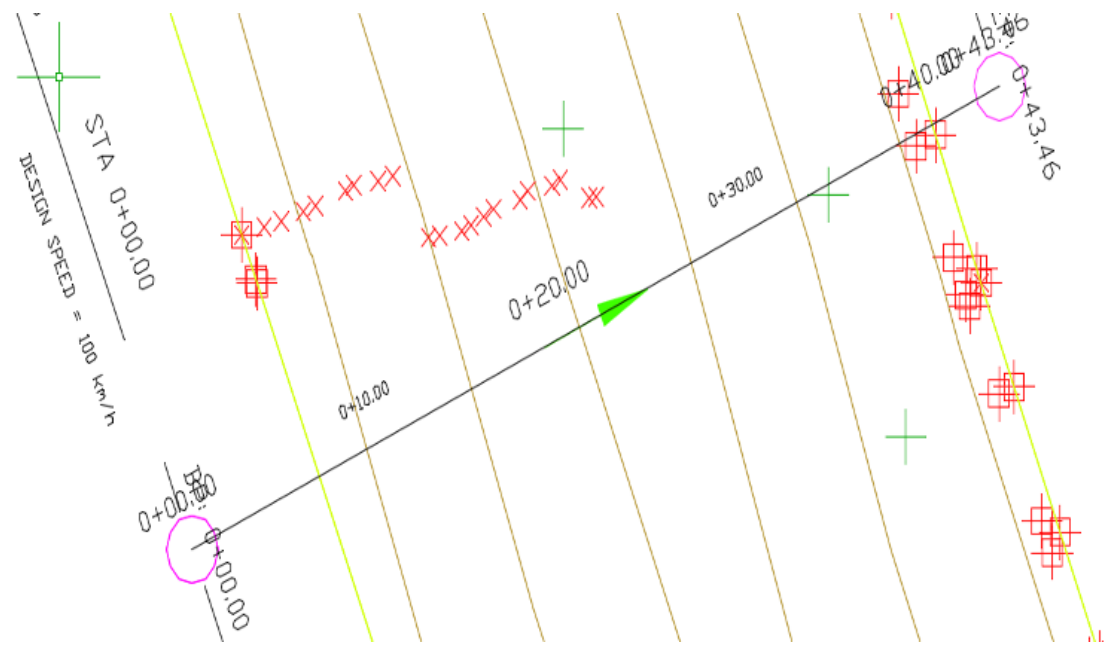

Figure 22 - Creating the cross-lines of a 3D model

Puc. 22 - Проектирование линий сечения ЗД модели

Слика 22 - Креирање линије пресека ЗД модела

When a cross section of the $3 \mathrm{D}$ model is created, it is also necessary to define the profile itself, i.e. which profile the concrete line of the cross section refers to. The most important settings are: select the cut line for the profile that is being created, add surfaces that will be included in the transversal profiles as well as other settings (layers, display styles). When the profile parameters are set (the profile to which it relates, the display styles, etc.), the specific profile is plotted, or it is confirmed on the drawing worksheet where the profile will be generated (Figure 23).

The generated profile layout contains information about the appearance of the zero surface (green line), the calculating surface (red line), the surface of the figure that the profiles limit, the height, etc. All other profiles are formed according to the same principle (total of twenty). Nineteen profiles are at distances of $25 \mathrm{~m}$, and the last one is at $4.85 \mathrm{~m}$ because this is the space left to the end of the excavation (Figure 24 and Figure 25). 
Profile View of Alignment - (6)

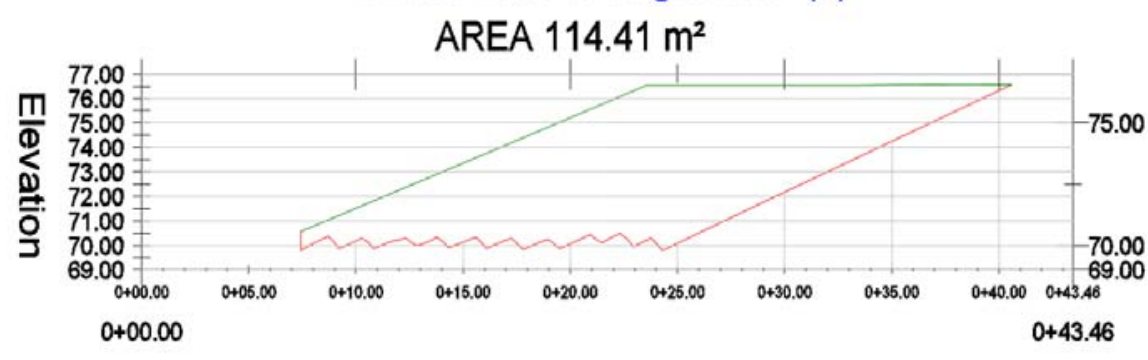

Figure 23 - Generating the profile layout

Pис. 23 - Генерирование вида профиля

Слика 23 - Генерисање изгледа профила
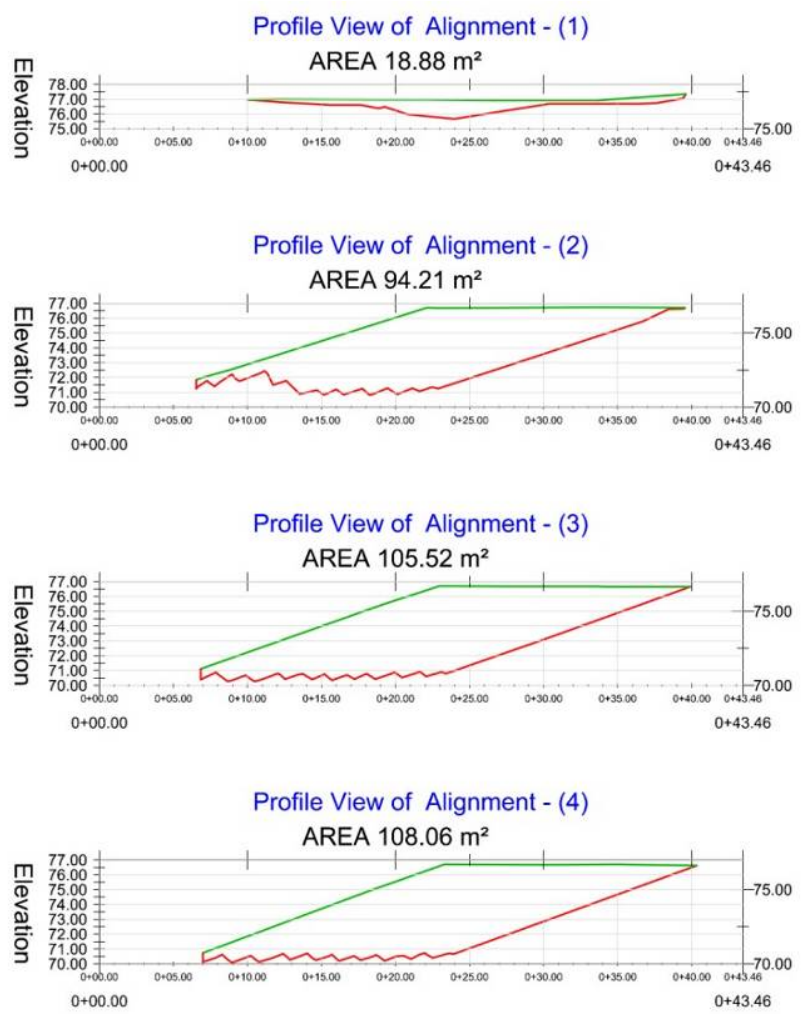

Figure 24 - Generated profiles from 1 to 4 Puc. 24 - Сеенерированные профрили с 1 до 4 Слика 24 -Генерисани профрили од 1 до 4 


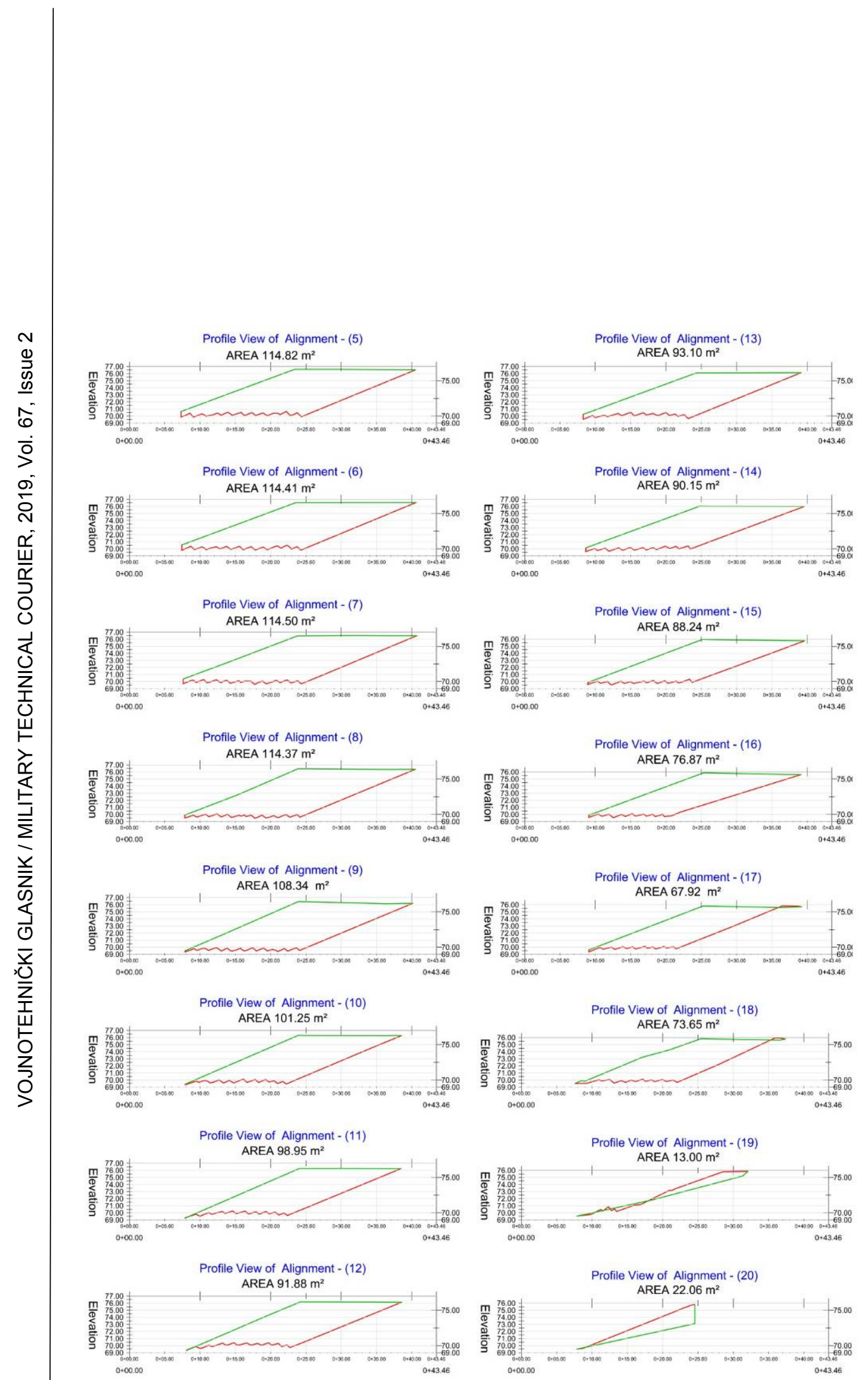

Figure 25-Generated profiles from 5 to 20

Puc. 25 - Сгенерированные профиили с 5 до 20

Слика 25 - Генерисани профрили од 5 до 20 
When the profiles and the surfaces of the figure limited by the lines of the zero and calculating surfaces are determined, the control calculation of the volume for the period of 2013 - 2014 can be carried out. The control of the calculation is performed in the following way: the individual volume of soil (clay) is defined, limited by the zero and calculating surfaces and two adjacent profiles. For determining such a volume, it is necessary to determine the mean value of the surface of the figures from two adjacent profiles, as the arithmetic mean of the formula:

$$
P_{i, \text { zapremine }}=\frac{P_{i}}{P_{i+1}}
$$

where is:

$P_{i, z a p r e m i n e}$ - the mean value of the figure surface area between two adjacent profiles;

$P_{i}$ - the area of the profile figure where there is the beginning of the individual volume;

$P_{i+1}$ - the area of the profile figure where there is the end of the individual volume.

Then, an individual volume value is calculated between each two adjacent profiles as the product of the mean value of the figure surface area and the distance between the profiles:

$$
V_{i}=P_{i, \text { zapremine }} * L_{i}
$$

where is:

$L_{i}$ - distance between two adjacent profiles (25m, except the last one).

The calculation results are shown in Table 1. The calculated volume value for the observed period of changes from 2013 to 2014, based on the cross sections, is $41889.52 \mathrm{~m}^{3}$. Bearing in mind the previously calculated volume which amounted to $42385 \mathrm{~m}^{3}$, or programmatically based on the formed $3 \mathrm{D}$ terrain models for 2013 and 2014, it can be considered that the obtained values of the volume are consistent to a large extent. The reason for the discrepancy between the results is that the generalization process occurs, or due to the deployment of the profile lines, when the cross-section profiles are plotted, the mentioned process leads to generalization and certain distortion of the results.

Since the matching of the results from these two counting processes amounts to $98.8 \%$, and on the basis of previous work experience, it can be considered that the volume obtained on the basis of the formed DTM is completely acceptable, i.e. obtained by auto-counting in AutoCAD Civil 3D. 
Table 1 - Calculation of the total volume of the excavation based on transversal profiles Таблица 1 - Расчет общего объема карьера на основании поперечных профилей Табела 1 - Рачунање укупне кубатуре ископа на основу попречних профила

\begin{tabular}{|c|c|c|c|c|}
\hline $\begin{array}{l}\text { Number } \\
\text { of the } \\
\text { profile }\end{array}$ & $\begin{array}{l}\text { Square of } \\
\text { the profile } \\
\left(\mathrm{m}^{2}\right)\end{array}$ & $\begin{array}{l}\text { Mean value of the } \\
\text { square figure }\left(\mathrm{m}^{2}\right)\end{array}$ & $\begin{array}{l}\text { Distance between } \\
\text { the profiles }(m)\end{array}$ & $\begin{array}{l}\text { Cubature between the } \\
\text { adjacent profiles }\left(\mathrm{m}^{3}\right)\end{array}$ \\
\hline 1 & 18.88 & \multirow{2}{*}{56.545} & \multirow{2}{*}{25} & \multirow{2}{*}{1413.63} \\
\hline 2 & 94.21 & & & \\
\hline 2 & 94.21 & \multirow{2}{*}{99.865} & \multirow{2}{*}{25} & \multirow{2}{*}{2496.63} \\
\hline 3 & 105.52 & & & \\
\hline 3 & 105.52 & \multirow{2}{*}{106.790} & \multirow{2}{*}{25} & \multirow{2}{*}{2669.75} \\
\hline 4 & 108.06 & & & \\
\hline 4 & 108.06 & \multirow{2}{*}{111.440} & \multirow{2}{*}{25} & \multirow{2}{*}{2786.00} \\
\hline 5 & 114.82 & & & \\
\hline 5 & 114.82 & \multirow{2}{*}{114.615} & \multirow{2}{*}{25} & \multirow{2}{*}{2865.38} \\
\hline 6 & 114.41 & & & \\
\hline 6 & 114.41 & \multirow{2}{*}{114.455} & \multirow{2}{*}{25} & \multirow{2}{*}{2861.38} \\
\hline 7 & 114.50 & & & \\
\hline 7 & 114.50 & \multirow{2}{*}{114.435} & \multirow{2}{*}{25} & \multirow{2}{*}{2860.88} \\
\hline 8 & 114.37 & & & \\
\hline 8 & 114.37 & \multirow{2}{*}{111.355} & \multirow{2}{*}{25} & \multirow{2}{*}{2783.88} \\
\hline 9 & 108.34 & & & \\
\hline 9 & 108.34 & \multirow{2}{*}{104.795} & \multirow{2}{*}{25} & \multirow{2}{*}{2619.88} \\
\hline 10 & 101.25 & & & \\
\hline 10 & 101.25 & \multirow{2}{*}{100.100} & \multirow{2}{*}{25} & 250250 \\
\hline 11 & 98.95 & & & $250 \angle .50$ \\
\hline 11 & 98.95 & 05415 & 25 & 238538 \\
\hline 12 & 91.88 & 95.415 & $\angle 0$ & 2300.38 \\
\hline 12 & 91.88 & 92490 & 25 & 231225 \\
\hline 13 & 93.10 & 92.490 & $\angle 0$ & $\angle 312 . \angle 3$ \\
\hline 13 & 93.10 & 91625 & 25 & 229063 \\
\hline 14 & 90.15 & 91.020 & $\angle 0$ & 2290.03 \\
\hline 14 & 90.15 & 89195 & 25 & 222088 \\
\hline 15 & 88.24 & 09.195 & $\angle 0$ & $\angle \angle \angle 9.00$ \\
\hline 15 & 88.24 & & & \\
\hline 16 & 76.87 & 82.555 & 25 & 2063.88 \\
\hline 16 & 76.87 & 72305 & 25 & 180088 \\
\hline 17 & 67.92 & 12.090 & 20 & 1009.00 \\
\hline 17 & 67.92 & 70785 & 25 & 176963 \\
\hline 18 & 73.65 & 10.185 & 25 & 1709.03 \\
\hline 18 & 73.65 & 43.325 & 25 & 1083.13 \\
\hline
\end{tabular}




\begin{tabular}{|l|l|l|l|l|}
\hline $\begin{array}{l}\text { Number } \\
\text { of the } \\
\text { profile }\end{array}$ & $\begin{array}{l}\text { Square of } \\
\text { the profile } \\
\left(\mathrm{m}^{2}\right)\end{array}$ & $\begin{array}{l}\text { Mean value of the } \\
\text { square figure }\left(\mathrm{m}^{2}\right)\end{array}$ & $\begin{array}{l}\text { Distance between } \\
\text { the profiles }(\mathrm{m})\end{array}$ & $\begin{array}{l}\text { Cubature between the } \\
\text { adjacent profiles }\left(\mathrm{m}^{3}\right)\end{array}$ \\
\cline { 1 - 2 } 19 & 13.00 & & & 85.02 \\
\hline 19 & 13.00 & \multirow{2}{*}{17.530} & 4.85 & $\mathbf{4 1 8 8 9 . 5 2}$ \\
\hline 20 & 22.06 & & \\
\cline { 1 - 2 } Total cubature:
\end{tabular}

Namely, the method of calculating the volume on the basis of transversal profiles can be used as a counting control, as is confirmed by the results. In addition to this control purpose, generating cross-sectional profiles plays an important role in verifying the 3D model, since it provides a clear image of the vertical cross-sectional view. In this case, it is clearly seen that the bottom of the excavation is saw-shaped and that one side of the excavation climbs steadily to the top, which absolutely corresponds to the actual situation on the ground.

Different types of information are contained in the generated transversal profile, for example, the slopes of the terrain. Also, the measurement of many elements shown in the transversal profile is enabled (Figure 26).

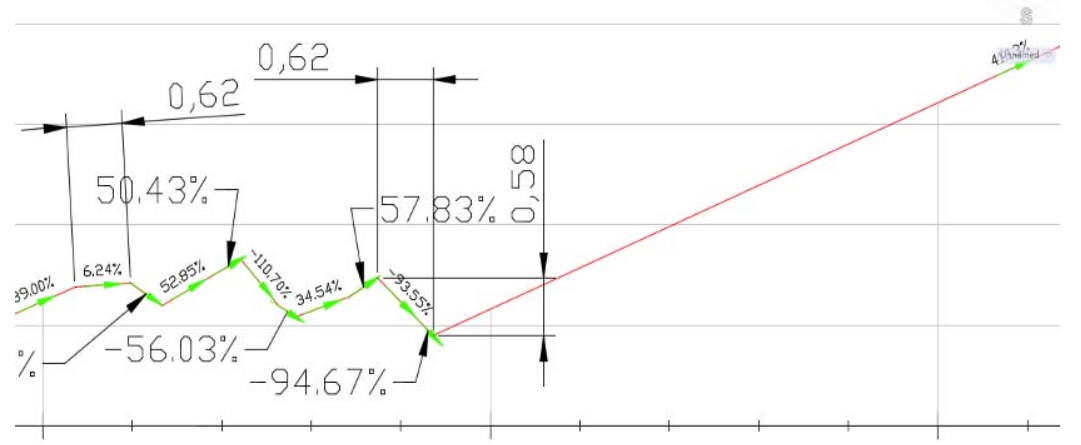

Figure 26 - Slopes of the surfaces shown on the transversal profile of the $3 D$ surface model

Puc. 26 - Уклоны на местности, изображенные на поперечном профиле ЗД модели

Слика 26 - Нагиби површи приказани на попречном профилу ЗД модела површи

Also, the surface can be more clearly and easily seen via the crosssectional view, so it is often used in design in construction works, traffic, hydrography, mining, etc.

\section{$3 D$ terrain model visualisation}

In the previous part, 3D modeling of the surface of the ground for different time moments $(2013,2014$, and 2015) was carried out, based on which different analyzes were performed in order to solve a certain type of problems 
(calculation of volume). In explaining these procedures, the formed 3D terrain models were interpreted in different ways (using contour lines, profiles, 3D solid models, etc.).

Visualization of the 3D model is one of the most important features. The way in which the information is transmitted to the user depends on the model itself. Styles, colors, data display, and viewing angles provide the field information that should be approximate to that that might be collected by observing actual surfaces on the ground. Also, visual verification is very important in controlling 3D modeling. Due to all of the above, several ways of presenting DTM will be displayed.

One of the most commonly used methods of displaying geomorphologic characteristics is contour lines. Based on the established DTM, this display mode is possible at any moment (Figure 27) and generating a model with a different equity is extremely simple and automatic (Figure 28).

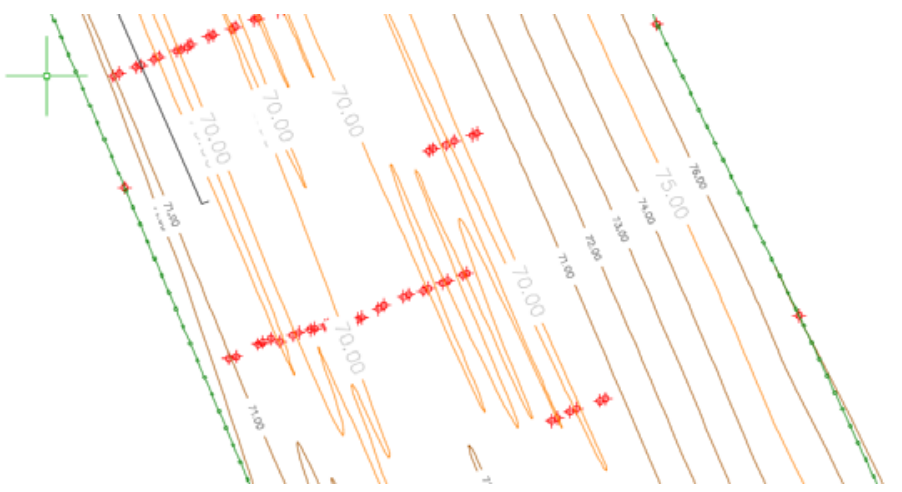

Figure 27 - Model display via contour lines - equidistance $1.0 \mathrm{~m}$

Pис. 27 - Изображение модели изогипсой - равенство отстояний 1.0 м

Слика 27 - Приказ модела преко изохипси -еквидистанција 1,0 m

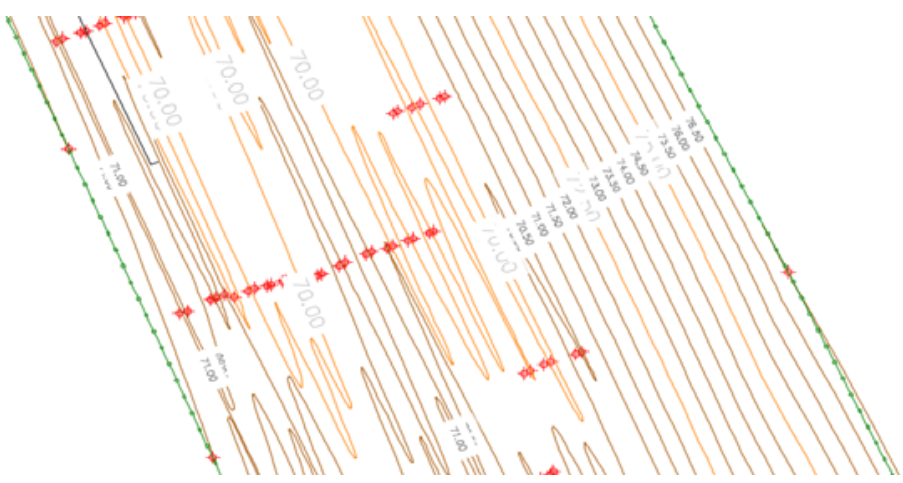

Figure 28 - Model display via contour lines - equidistance $0.5 \mathrm{~m}$

Puc. 28 - Изображение модели изогипсой - равенство отстояний 0.5 м

Слика 28 - Приказ модела преко изохипси - еквидистанција 0,5 m 
To see the triangles formed during triangulation, one of the good ways of displaying is a wired model (Figure 29) or a shady solid model made up of threedimensional facets (Solid model - 3d faces) shown in Figure 30.

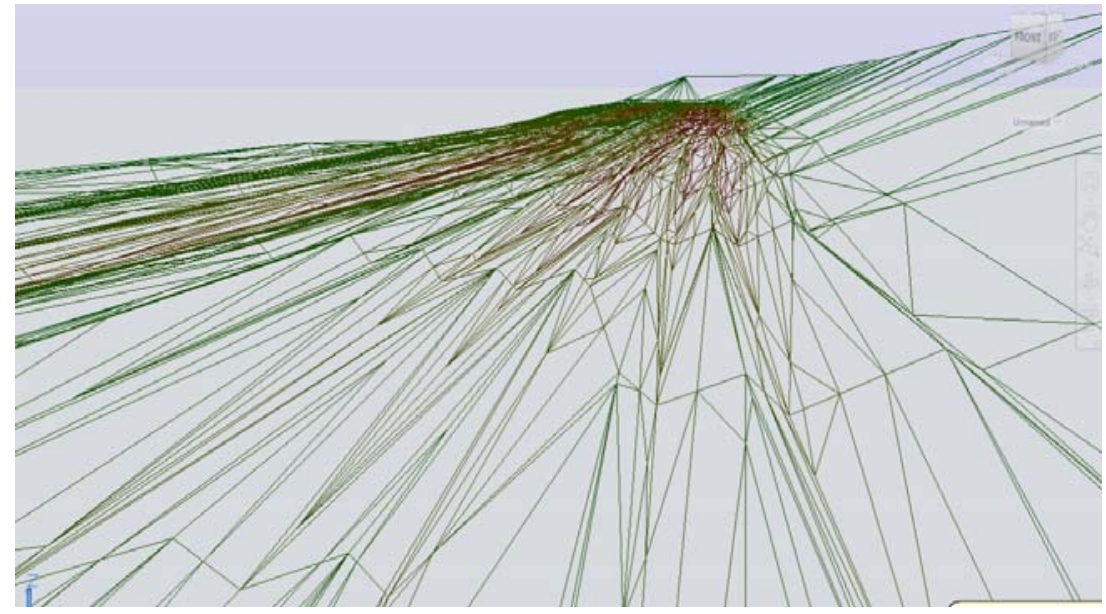

Figure 29 - Wired 3D model

Puc. 29 - Каркасная ЗД модель

Слика 29 - Жичани ЗД модел

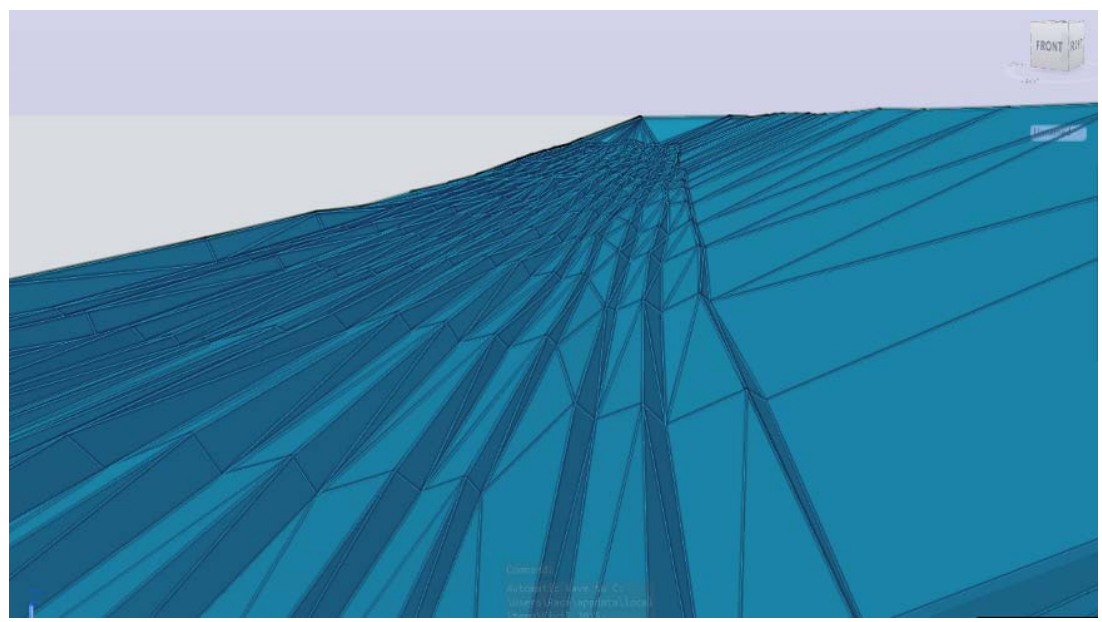

Figure 30 - Shaded model composed of triangular facets

Рис. 30 - Модель затенения, состоящая из треугольных граней

Слика 30 - Сенчени модел који се састоји од троугаоних фрасета 


\section{Conclusion}

The paper presents the entire process of creating and forming 3D models, from measuring and data processing to displaying and monitoring changes in the capacity of the "Garajevac - Istok " mine. The research and analysis pallete that can rely on the image of the digging profile and its three-dimensional display is far more extensive. The primary analysis is to monitor changes in the shape and capacity of the excavation during the exploitation of clay during the subsequent period (2013-2014, 2014 - 2015).

3D models were formed on the basis of the data collected on the terrain by terrestrial recording by the total station and taken from the already existing digital maps and plans. Progress in terms of improving the technique of collecting data on the field is certainly possible, first and foremost, by using modern methods of recording (laser recording, photogrammetry). However, in order for various planners, engineers and local services to use depth measurement data on a daily basis and to have the latest state available, it is useful to establish a geoinformation system. Such a system requires constant data updating and its upgrading to new data layers. In this way, a rich database will be obtained, useful primarily for a rapid development of 3D excavation models, precise profiles and various thematic maps.

\section{References}

-Autodesk. 2018. Products, 3D CAD SOFTWARE, AutoCAD Civil 3D. [Internet] Available at: http://www.autodesk.com. Accessed: 28.10.2018.

Arrighi, P., \& Soill, P. 1999. From Scanned Topographic Maps to Digital Elevation Models. In Proc. of Geovision'99, International Symposium on Imaging Applications in Geology, USA.

Ceylan, A., Karabork, H., \& Ekozoglu, I. 2011. An analysis of bathymetric changes in Altinapa reservoir. Carpathian Journal of Earth and Environmental Sciences, 6(2), pp.15-24. Available

at:

http://www.ubm.ro/sites/CJEES/viewTopic.php?topicld=152. Accessed: 21.09.2018.

Chappel, E. 2014. AutoCAD Civil 3D 2015 Essentials.Indianapolis, Indiana, USA: Autodesk Offical Press.

Cross, B.K., \& Moore, B.C. 2014. Lake and reservoir volume: Hydroacoustic survey resolution and accuracy. Lake and Reservoir Management, 30(4), pp.405-411. Available at: https://doi.org/10.1080/10402381.2014.960115.

-Environmental Systems Research Institute (ESRI). 2010. "Using Arc GIS 3D Analyst", User Guide.Redlands, USA.

Li, Z., Zhu, Q., \& Gold, C. 2005. Digital terrain modeling - principles and methodology.Florida, USA: CRC Press.

Omura, G., \& Benton, C.B. 2013. Mastering AutoCAD 2014 and AutoCAD LT 2014.Inianapolis, Indiana, USA: Autodesk Offical Press.

Simon, B.J., \& Howel, J.A. 2007. Terrestrial laser scanning in geology: Data acquisition, processing and accuracy considerations.London, UK: The Geological Society of London. 
Šiljeg, A., Barada, M., \& Marić, I. 2018. Digitalno modeliranje reljefa.Zadar: Sveučilište u Zadru (in Croatian).

Zhang, L. 2005. Automatic Digital Surface Model (DSM) Generation from Linear Array Images.Swiss: Swiss Federal Institute of Technology. A dissertation submitted.

АНАЛИЗ ИЗМЕНЕНИЙ ОБЪЕМА КАРЬЕРА «ГАРАЕВАЦ ВОСТОК», ВЫПОЛНЕННЫЙ С ПОМОЩЬЮ ГИС ТЕХНОЛОГИИ

Мирко А. Борисов ${ }^{\text {a }}$, Радован В. Симич ${ }^{6}$, Владимир М. Петрович Богдан Б. Бойович

а Университет в г. Нови-Сад, Факультет технических наук, Департамент информатики и автоматики, г. Нови-Сад, Республика Сербия

${ }^{б}$ Геодезическая мастерская «АШ», г. Нови-Сад, Республика Сербия

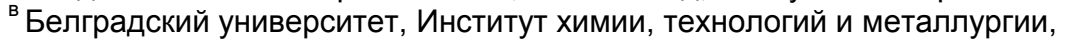
Центр экологии и техноэкономики, г. Белград, Республика Сербия

г Республиканское геодезическое ведомство, г. Белград, Республика Сербия

РУБРИКИ: 36.23.00 Прикладная геодезия. Прикладные применения аэросъемки и фотограмметрии

ВИД СТАТЬИ: профессиональная работа

ЯЗЫК СТАТЬИ: английский

\section{Резюме:}

В данной работе рассматривается проект разработки и наблюдения за изменениями объема карьера «Гараевац-Восток», находящегося на кадастровой карте муниципалитета НовиБечей. Надо подчеркнуть, что раньше фризическая площадь и геопространство в целом, представлялись двумерно (2Д), на плоскости, с помощью оного из картографических методов (изолинии, высотные отметки, гипсометрия) или трехмерно (ЗД) с помощью проектирования моделей и рельесрных карт. Картографрические принципы визуализации местности на рельефрных картографических моделях позволяют создавать ЗД изображения, но они с инженерной точки зрения, были недостаточно качественными и точными. При этом сложно было проводить количественную и качественную оценку местности на вышеупомянутых моделях. Однако благодаря современным технологиям меняется и ЗД изображение геопространства, то есть применяется концепция разработки цифровой модели местности (ЦММ). Главная цель настоящей работы заключалась в создании ЗД модели и проведении сравнительного объема карьера «Граевац-Восток» в течение определенного эксплуатационного срока.

Ключевые слова: карты, ГИС, объем, изменения на местности, ЦММ, анализ. 


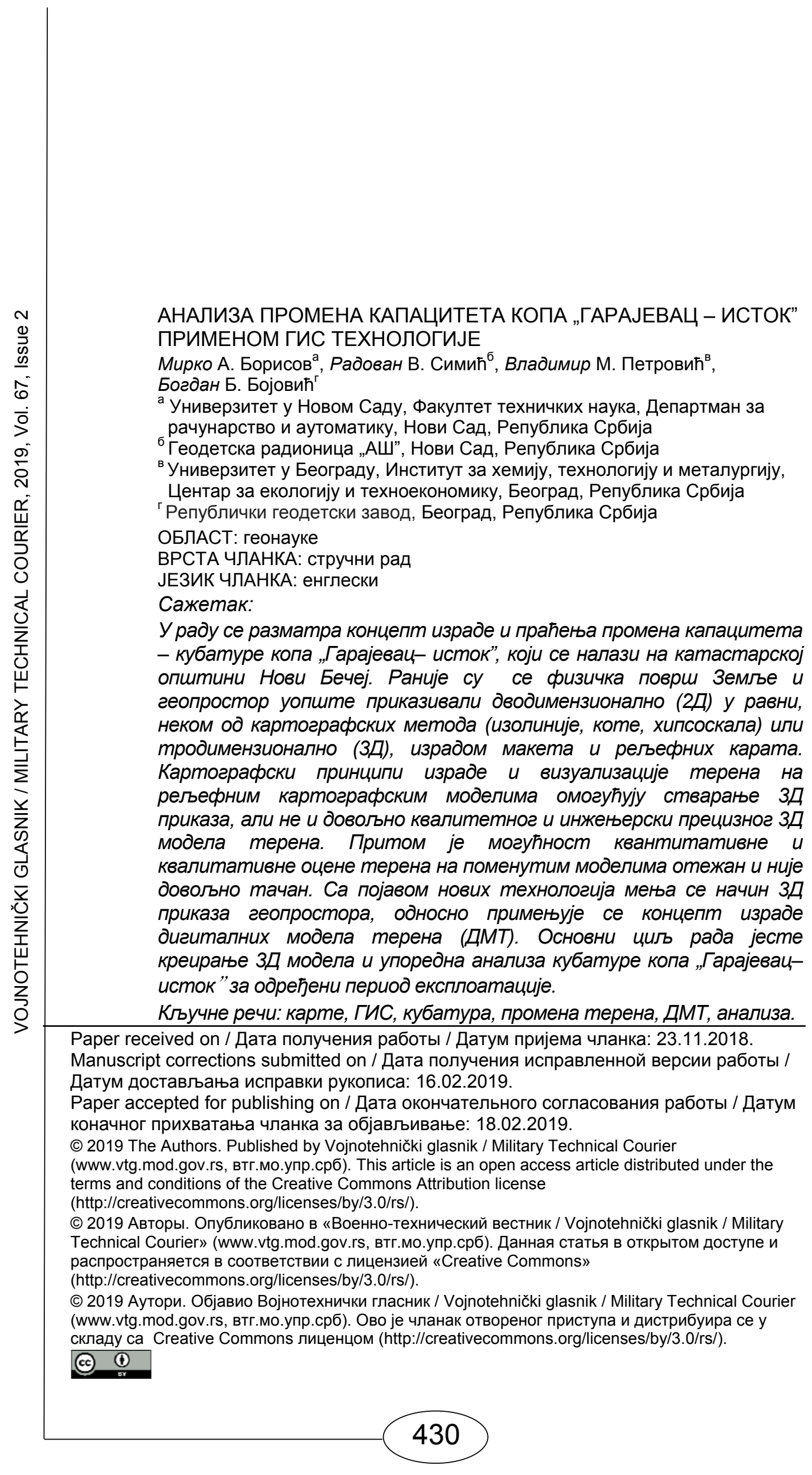

